\section{Lange-Müllers hovedpine - hvad kom den af?}

\author{
Aflage Benedicte Egede Glahn
}

"Jeg har endog i Dag en lille Tid varet helt fri for Hovedpine og forbauser mig over, at Folk, der har det saadan altid, ikke synger og jubler fra Morgen til Aften".

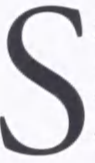
ådan skrev komponisten P.E. LangeMüller (1850-1926) under en vandretur i Pyrenæerne 27 år gammel. Denne hovedpine manifesterede sig allerede ved 5-6 års alderen. Den fulgte ham kronisk hele livet og lagde tungsind og frustration over både personlighed og gerning. Han skriver som 30-årig: "Hvorledes skulde jeg ogsaa komme videre? Al Studeren og Tilegnen er en Umulighed paa Grund af Hovedpinen, og al Udarbejden af mit eget ligesaa". I begge biografier (Julius Clausen: P.E. Lange-Müller, Mennesket og Kunstneren, Haase \& Søn 1938, og Helge Bonnén: P.E. Lange-Müller, Jespersen \& Pio 1946) er hovedpineproblemerne og deres afgørende betydning for liv og virke velbeskrevet, dels baseret på breve og dagbøger fra hans yngre år, dels på supplerende oplysninger fra hans ældste datter (Irmelin g. Glahn), som var min mor. Men årsagen til hovedpinen er kun løseligt omtalt, således hos Clausen (p. 14) blot "en øjenanomali”, idet der ikke dengang var samme opmærksomhed om personlige detailler, som nu. De senere års genopblussende interesse for hans musik synes imidlertid også at øge interessen for at gå tæt på ham selv. Det har vist sig, at den nærmere forklaring på hans hovedpine kun er kendt i familien, og da der nu begynder at fremkomme diverse vildfarne hypoteser (f.eks. i DR's magasin Klassisk Musik Dec 2000) og man i radioen omtalte "Gåden om LangeMüllers hovedpine" forekommer det rimeligt at orientere om de faktiske forhold, dels baseret på familiebreve (Det Kgl.

Bibliotek, Håndskriftsamlingen katalogsign. (tilg.) 315, kapsel 6, hvorfra efterfølgende brevcitater stammer), og dels på hvad min mor og hendes søstre fortalte.

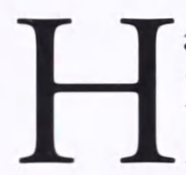
an var såmænd "bare" meget langsynet på det ene øje og nærsynet på det andet, fortalte mor, og da det omsider blev opdaget ved 62-års alderen havde øjenspecialisten sagt til ham: "Hvis De havde mistet det ene oje som barn, ville alle have ynket Dem og set det som en tragedie, men i virkeligheden ville det have betydet, at De aldrig havde haft mere hovedpine end almindeligt, og dermed nok et langt bedre liv". Tilstanden kaldes anisometropi: forskellig længde af øjenaksen forfra-bagtil. Et langsynet øje er for kort, et nærsynet for langt, i forhold til øjets brydningsstyrke (i hornhinde og linse), så lysstrålerne med øjet i hvile ikke får brændpunkt på nethinden, som normalt, men samles hhv. bagved og foran. Se ill. med tilhørende tekst side 4-5.

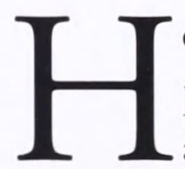
ovedpinen og den fysiske og psykiske udtrætning (stress, asthenopia) kom af de 2 øjnes meget forskellige bygningsfejl, som giver konstant overaktivitet i de involverede muskler, nerver og hjernecentre under anstrengelse for at justere synet som beskrevet i tekst til illustrationen. Lange-Müller blev tidligt undersøgt af kompetente øjenlæger, men tidens viden og udstyr - for ca 150 år siden - rakte åbenbart ikke til 


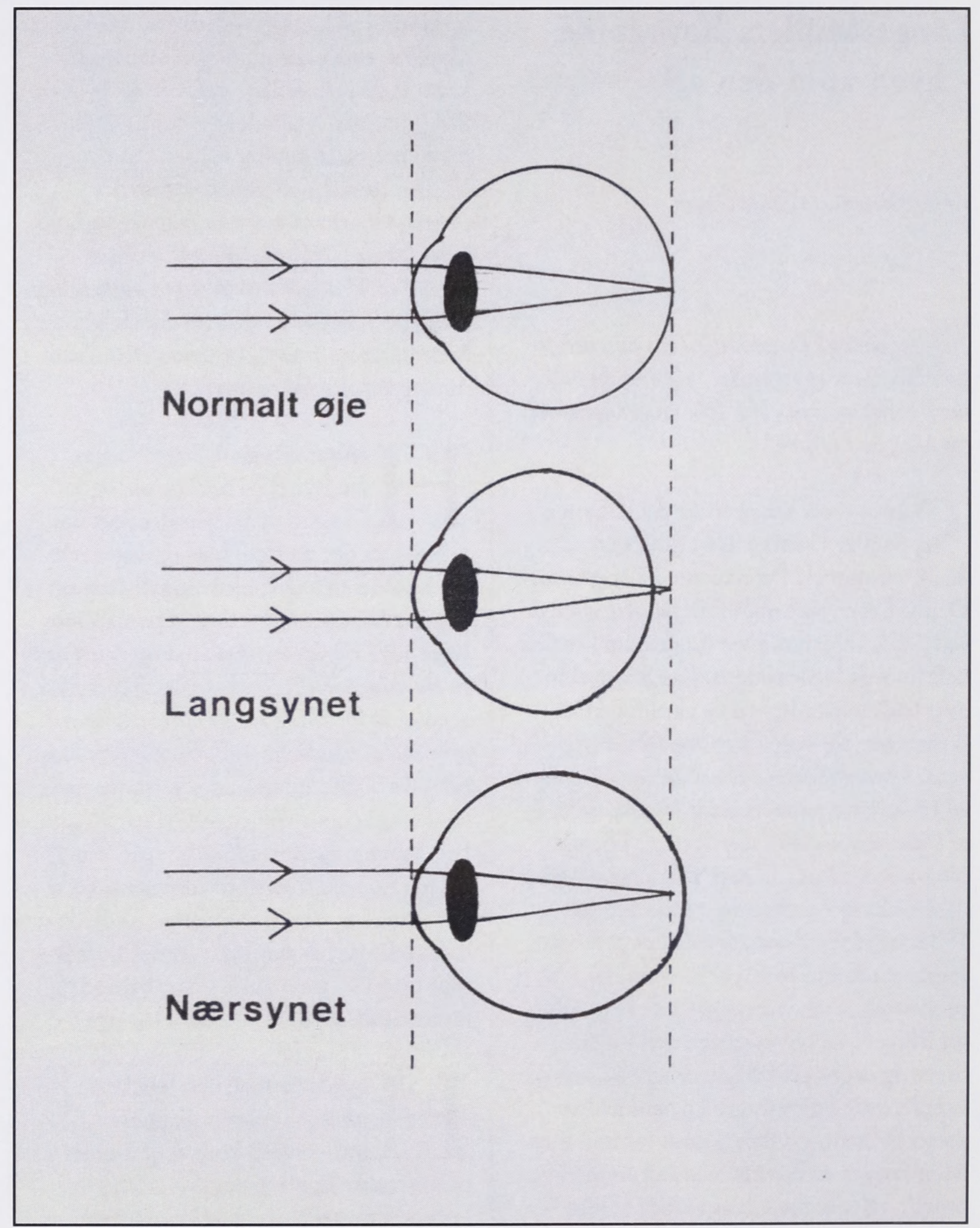

\section{Grundtræk af øjnenes forhold}

Til skarpt syn skal indkommende lysstråler fra det vi ser på bøjes (brydes) via hornhinden og linsen til brændpunktet ligger på nethinden på øjets bagvæg. Herfra går

1 nerveimpulser bagud til synscentre i hjernen, hvor de samordnes fra begge øjne til et fælles billede, som videresendes til vor bevidsthed. 
I et normalt øje har linsen en brydningsstyrke der passer med dens afstand fra nethinden sådan, at parallelle stråler ved afstandssyn (over 6 meter) samles på denne (se tegning). Ved syn på nærmere hold er strålerne ikke mere parallelle, hvorfor linsens styrke må øges, desmere jo nærmere genstanden er, for stadigt at holde brændpunktet på nethindens plan.

Linsen er bygget af materiale som giver den en vis indre spænding og er ophængt i tråde langs hele randen ud til en slags ringmuskel i hele periferien. Musklen hæfter til øjets væg og er afslappet i hvilestilling ved afstandssyn, men varierende sammentrukket når linsens brydningsstyrke skal øges til nærmere syn. I takt med musklens grad af sammentrækning slækkes jo trådene, og så bevirker linsens egenspænding, at den tenderer mod at "kugle" sig tilsvarende, så krumningen (tykkelsen) og dermed brydingsstyrken øges. Denne mekanisme er det centrale i øjets "akkomodation", dvs. justering til skarpsyn på nærmere afstande. Akkomodationen styres reflektorisk (automatisk/ubevidst) af nerveimpulser mellem hjernens synscentre og øjnene, hvis indstilling løbende tilpasses afstanden til det, vi ser på. Med alderen aftager linsens elasticitet så krumningsevnen aftager og vi bliver langsynede: nære ting ses uskarpt, vi prøver at holde dem på længere afstand, men læsning, skrivning o.l. giver tiltagende træthed og hovedpine p.g.a. akkomodationsanstrengelserne og det uskarpe billede. Den reducerede linsekrumning må kompenseres med samlelinser i tilsvarende styrke: læsebriller.

Et nærsynet øje er for langt: linsens styrke i hvile er da relativt for stor, så brændpunktet falder foran nethinden (se tegning). Kun ved at mindske afstanden til det iagttagne skubbes brændpunktet bagud til nethinden, så billedet bliver skarpt. Over en vis afstand ses alt uskarpt uden hjælpemidler (spredelinser).

Omvendt er et langsynet øje for kort, så brændpunktet ligger bag nethinden (se tegning). For at trække det frem til nethinden må akkomodationen aktiveres i langt højere grad end normalt og specielt maksimeres ved almindelig arbejdsafstand til læsning, skrivning o.l. Kun over lang synsafstand kan øjets muskler og nervesystem slappe af, men ved stærk langsynethed kan den ustandselige anspændelse af akkomodationen stige til kronisk aktivitet, den kan ikke mere afslappes (akkomodationskrampe). Også muskler som regulerer pupilstørrelse og blikretning er involveret i akkomodation, styret reflektorisk. Det er overaktiviteten i alle de involverede muskler, nervebaner og hjernecentre, der forårsager hovedpine og stresssymptomer ved langsynethed.

Men hertil kommer som nævnt, at der i hjernen skal ske en samordning af synsindtrykkene fra begge øjne, fra deres nethindebilleder (samsyn). Men de to øjne kan kun i meget ringe omfang akkomodere uafhængigt af hinanden, så ved et nærsynet og et meget langsynet øje, som hos Lange-Müller, vil det ikke være muligt at opnå et skarpt billede fra begge. Differencen mellem dem vil kun kunne mindskes minimalt, uanset synsafstand og akkomodationsanstrengelser. Et af dem vil hele tiden være uskarpt og bliver da undertrykt i hjernen, som udvælger det skarpe til vor bevidsthed. Også denne ekstra hjerneaktivitet medvirker i udtrætningen.

(Illustrationen er tegnet af arkitekt m.a.a.Henrik C. Egede Glahn, pens. lektor ved Kunstakademiets Arkitektskole). 
korrekt diagnose. Måske også fordi børns og unges indstillingsevne, den såkaldte akkomodationsevne er så stor, at den kan kamuflere selv stærk langsynethed. Dertil kommer, at den vanemæssige overaktivitet af akkomodationen i de svære tilfælde kan reducere effekten af de atropindråber, man bruger før synsprøven for netop at lamme akkomodationen og undgå fejlvurdering af langsynethed. Det nærsynede øje giver ikke i sig selv anledning til hovedpine, men det gør den udtalte langsynethed på det andet og differencen imellem deres respektive bygningsfejl. Når man flere gange som ung får den besked, at hovedpinen ikke stammer fra øjnene, søger man naturligvis andre veje efter forklaring eller hjælp. Han prøvede alverdens kure - naturligvis alt forgæves.

$\mathrm{P}$ å denne baggrund blev han derfor umådelig forbløffet, da han i 1913 i anden anledning blev set af før-

nævnte øjenspecialist, som ikke kendte ham forud, og denne ved undersøgelsen udbrød: "Sig mig, Hr. Lange-Müller, har De ikke altid hovedpine?"-? - "Jeg kan se det på Deres Øjne!", som mor fortalte. Det gik sådan til:

Morfar og mormor tilbragte en del af vinteren 1912-13 i Egypten af helbredsgrunde: mormor havde en nyrelidelse, som diætkure kunne afhjælpe en tid (nefrose, som hun døde af i 1921) og morfar håbede på lindring i det tørre, lune klima. Herfra skriver begge hjem til ældste datters 18-års fødselsdag 13. Febr. 1913.

Morfars fødselsdagsbrev er dateret "Assuan, d. 31. Jan.", stemplet bagpå: Cairo 2.II. 1913 (frimærket bortklippet). På sidste side skriver han: "... og saa fik jeg en Øjenbetondelse (en lille "agyptisk Øjensyge") som nu i en halv Snes
Dage har forhindret mig i at lase og skrive. $\mathrm{Nu}$ er den heldigvis saa godt som forbi; det er en markelig gammel Doktor paa 83 Aar, som har kureret den; han er her som Gjest paa Hotellet ligesom vi, er verdensberomt og meget original. Han paastaaer, at min Hovedpine stammer fra, at jeg seer i forskjellig Højde med Øjnene, og at han kan kurere det, hvis jeg vil komme til ham i Paris."

\section{Mormors brev ( i samme} konvolut) har som hoved: „Cataract Hotel, Assouan. Upper Egypt 1/2.1913, Africa“. Om morfars øjne skriver hun:

"... den gamle Professor lagger ogsaa megen Beslag paa hans [Lange-Müllers] Tid, og da Ojnene endnu skal passes med Boervands-Vask og en halv Times Blyvands Omslag 3 Gange daglig gaar Tiden jo hurtigere end for. Nu maa Nabbi [morfar] ogsaa begynde at lase lidt igjen med Forsigtighed. Dersom denne gamle Professor virkelig kunne hjalpe paa Faers Hovedpine ved Hjalp af Briller, saa var det jo magelost, Nabbi tror ikke rigtigt paa det og har skrevet og spurgt Onkel Jan [Overlæge på Kommunehospitalets $\varnothing$ jenafd., Christian Bentzen, g.m. mormors søster]; derpaa vil det saa bero, om han lader sig behandle..."

Mormor skriver på selve mors fødselsdag "Assouan 13/2, 13": "... Det var en ordentlig Forskrakkelse, da vi horte, det var begyndende Agyptisk Øjensyge. I Aftes skulle Nabbi sidde en halv Time med Blyvandsomslag og i Morges var Øjnene nasten som de plejer at vare. I kan tro den gamle Professor er en Beromthed; det fik vi da Bevis for $i$ Gaar. Han spiser for vi Andre og Nabbi var gaaet ned for at traffe ham og sporge, hvornaar han skulle ses paa. Saa kom de andre Middagsgaster efterhaanden og Storfyrst Michael, som just trafpaa dem [Professoren og Nabbi] standsede og hilste paa Professoren, 


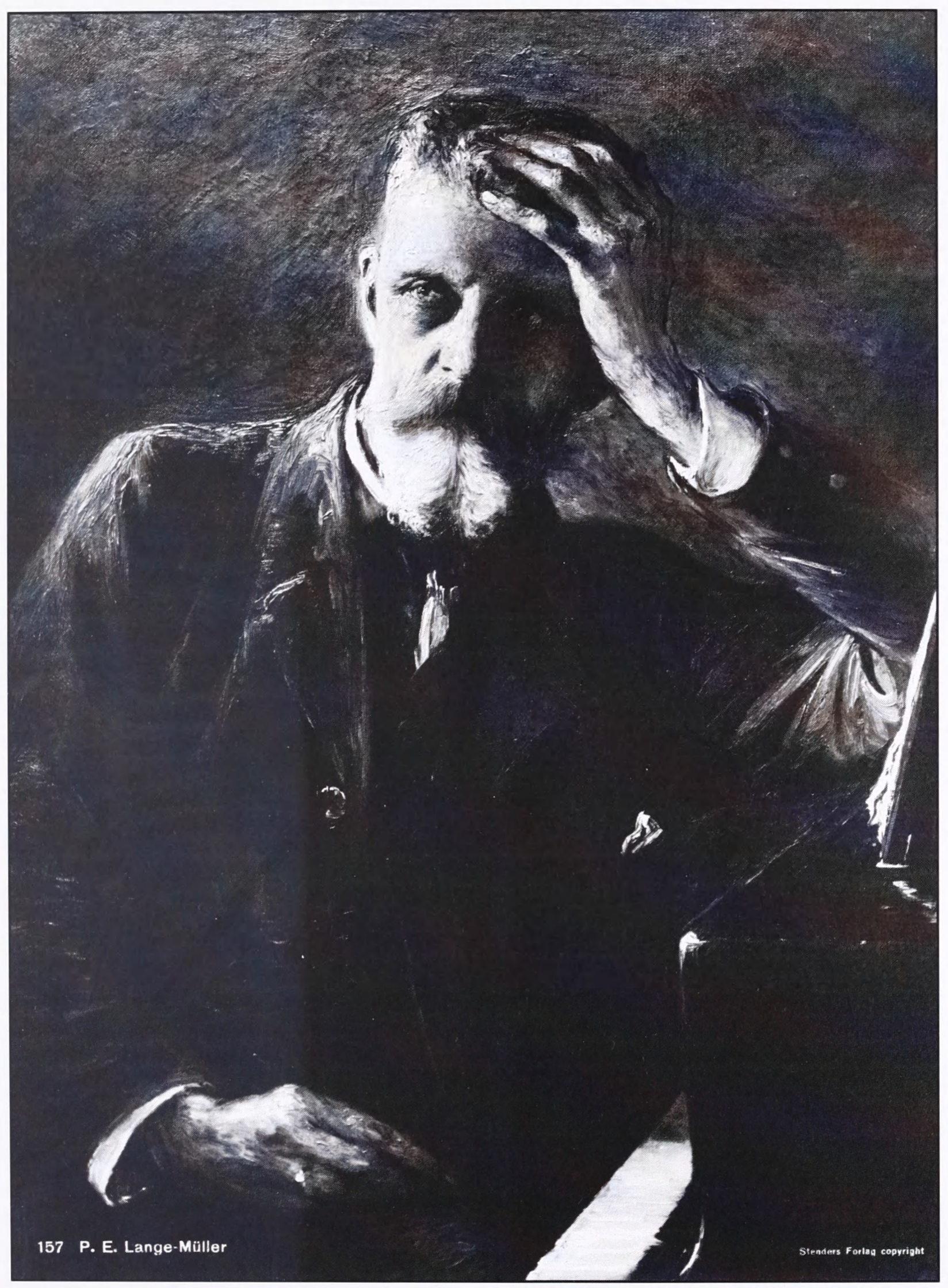

P.E. Lange-Müller (1850-1926). Kopi affotografisk gengivelse af Bertha Wegmanns portret af komponisten. Malet 1908 til Frederiksborgmuseet (Foto: Det Kongelige Bibliotek, Billedsamlingen). 
gledede sig ved at traffe ham her, sidste Gang var ved hans Tantes (?) Øjenoperation, og han navnede ogsaa en anden Person af den russiske Kaiserfamilie, som han var bleven kaldt til som Specialist, helt fra Paris. Professoren hedder Liebreich, er 83 Aar gammel, men lige saa lebendig som I. [Døtrene hjemme er 14, 16 og 18 år]. Han rejser igjen om 14 Dage hjem til sin Klinik i Paris, hvor han saa skal slide $i$ det til han igjen tager sig en Ferie i August. $N u$ kommer det markeligste. Han siger, at Nabbi's Hovedpine kommer fra hans Øjne, som han bruger forkert, fordi de sidder forkert i Hovedet, det ene hojere end det andet. Han sagde straks, at Nabbi havde Hovedpine og at det var Grunden. "De kan slet ikke bruge Deres Øjne uden at faa Hovedpine; men jeg skal skaffe Dem af med den, dersom De vil gaa med Briller, som jeg skal lave til Dem. Det er ikke det forste Tilfalde jeg har truffet, og jeg har altid kureret det". Tank om Nabbi skulde herned og faa daarlige Ojne for at consultere den gamle Proff. Liebreich og blive af med sin Hovedpine! Men han vil have Nabbi til Paris, her kan han ikke gjore ham fordig."

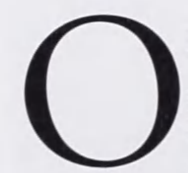
rdet "højde" forvirrer! Forklaringen ligger $i$, at samtalerne med Liebreich utvivlsomt er foregået på fransk, tidens europæiske fællessprog, som både morfar og mormor talte ubesværet og flydende, og Professoren har gennem de seneste 36 år levet i Paris med sin store klinik. Han har følgelig sagt på fransk, at morfar ikke så "au même niveau" med øjnene. Niveau betyder jo såvel højde som plan, og uden kedskab til øjnenes forhold, har det været nærliggende her i første omgang at misforstå forklaringen som niveauforskel op-ned = højde, som mormor tydeligvis har gjort. Trods samme misforståelse citerer morfar øjenlægen korrekt - at han "ser i forskellig højde med øjnene", blot skulle han have beholdt det franske ord niveau, eller oversat det med ordet "plan", da det drejer sig om forskudte vertikalplaner, niveauforskel forfra-bagud: med et hhv. nærsynet og langsynet øje "ser" man netop "i forskelligt plan", fordi bagvæggen med nethinden ligger i forskellig dybde (det ene øje er længere forfra-bagtil end det andet, se tegningen) og det er nethinderne man "ser" med, da det er dem som registrerer synsindtrykkene og sender impulserne videre til hjernens synscentre og vor bevidsthed om det vi ser.

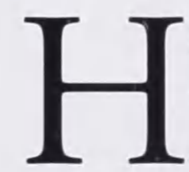

erudover foreligger der ikke mere skriftligt, intet om hvor eller hvem der fulgt sagen op (og min

generation glemte at spørge mens tid var!).

Det var mor og hendes søstre, som fortalte at slutdiagnosen blev som anført: han var stærkt langsynet på det ene øje, nærsynet på det andet, og prøvede efterfølgende at få briller. Det viste sig dog, at han kun kunne hjælpes med korrektionsglas for det ene øje, det andet skulle blindes med mat glas.

Desværre kunne han ikke i den alder vænne sig til pludselig at blive enøjet med tab af afstandsbedømmelse og det halve af sit synsfelt: man går ind i dørkarme, halvåbne døre, møbler o.l., falder over ting, snubler på trapper, tager og sætter ting forkert så de vælter, bliver usikker i alle vante gøremål. Det er velkendt som svært og belastende, og han var for gammel med sine 62 år, så han opgav. Tilstanden kan ikke afhjælpes med brilleglas-korrektion for begge øjne: ganske vist kan dette give et skarpt billede på begge nethinder, men glassenes afstand foran øjnene bevirker stor forskel på størrelsen af billedet på de 2 nethinder, så man får blot erstattet det primære problem (forskel i skarphed) med et andet (forskel i størrelse), men stadigt ikke et tydeligt fællesbillede 
(samsyn). Først med kontaktlinser har man fået et egnet hjælpemiddel, de sidder så tæt på øjnene, at forskellen i billedstørrelse bliver lille nok til at hjernen kan acceptere den uden problemer. Det er i øvrigt typisk, at øjenanomalien først manifesterer sig med symptomer i 5-6 års alderen når barnet begynder at bruge synet til den korte arbejdsafstand ved læsning og skrivning; ligeså forklarer den, at morfar i de unge år fik lindring af hovedpinen ved gartnerarbejde (større arbejdsafstande) og ved gåture i åbne landskaber og bjergvandringer hvor øjnene blev skånet for anstrengelse ved akkomodation til nærmere afstande. Det var dette, som hjalp, ikke "den friske luft". Med årene bliver linsen stivere, så anstrengelsen ved akkomodation øges og efterhånden kan den involverede muskulatur ikke mere afslappes (akkomodations-krampe) så mulighederne for lindring svinder. Iflg. mor sagde Liebreich, at morfar havde "krampe" i øjenene - der må have været tale om denne tilstand, som Liebreich selv har publiceret en artikel om (Archiv für Ophthalmologie, 8: 259-270, 1861).

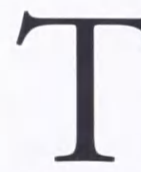

roværdigheden af Liebreich's vurderinger hviler i høj grad på, hvem han var. Iflg. nekrologen (Klinische Monatsblätter für Augenheilkunde, vol. 58, p. 566-576, 1917) var Richard Liebreich (1830-1917) en dynamisk og farverig person, tysk født i Østpreussens hovedstad Königsberg (nu russisk Kaliningrad), lægeuddannet forskellige steder i Tyskland, dr.med. 1853 og i 1854 62 videnskabelig assistent ved von Gräfe’s højt ansete øjenklinik i Berlin. Den var et dynamisk centrum for uddannelse, forskning og behandling netop disse år, hvor den moderne oftalmologi (læren om øjet) var i sin vorden, som følge af det lige opfundne øjenspejl: oftalmoskopet, et instrument til undersøgelse af øjets indre. De fleste af os har oplevet at blive lyst/kigget "dybt" i øjnene med den moderne udgave ved almindelig øjenundersøgelse. Liebreich var levende engageret i denne nye verden og skrev anerkendte artikler om sine iagttagelser og tolkning af dem. Han videreudviklede og forfinede teknik og metoder og udsendte sit hovedværk 1863: Atlas der

\section{Ophthalmoskopie på basis af disse års} banebrydende studier. Det var den første fremstilling af øjenbaggrunden ved normale og sygelige tilstande. Værket blev meget rost og anerkendt og kom i 3 oplag i løbet af de næste årtier. Han havde selv udført alle 57 afbildninger incl. farver, og personligt medvirket til illustrationernes overførsel til sten i Berlin - en grundig mand.

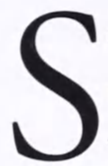
elv var han året før udgivelsen flyttet til Paris, hvor han denne første periode virkede 1862-70. Her var næsten ingen øjenspecialister - der herskede en vis generel fordom mod specialister, som ikke rigtigt ansås for fuldgyldige læger(!). De fleste var autodidakte og få vidste noget videre om de oftalmoskopiske landvindinger. Men Liebreich overbeviste både autoriteterne og pariserlægerne om den moderne oftalmoskopis betydning og vandt sidstnævnte for sig ved at undervise dem i metoden, mens han fik sig en stor og blomstrende praksis selv. Blandt patienterne var kejserindens mor, som han blev betroet at operere for grøn stær. Da resultatet var vellykket forlangte kejserinden, at man skulle overdrage Liebreich en lærestol i øjensygdomme ved det medicinske fakultet. Men det blev for meget, der rejste sig et ramaskrig af brødnid og ”- en udlænding!". Så Liebreich måtte bede ministeren afvise forslaget. Han var i øvrigt formand for 
Société medicale allemande, et samlingssted for alle tyske læger med fast eller midlertidigt ophold i Frankrig, så han har haft brede kontakter.

Med den fransk-tyske krig i 1870 måtte alle tyske forlade Paris og Liebreich valgte London. Også her var han heldig, men utvivlsomt også noget mere end det, eftersom han fik overdraget øjenafdelingen på det nyeste og bedst udrustede hospital, Sct. Thomas Hospital. Han fik også igen en stor praksis og var som altid bredt engageret, bl.a. skrev han 1873 om en selvopfunden indretning til forebyggelse af skadelig påvirkning af øjnene hos skolebørn ved at kunne variere hældningen på deres pulte. Han var hele livet tiltagende engageret i malerkunsten med gode egne evner. I Londontiden vakte han furore i kunstnerkredse ved 1872 at skrive On Defects of Vision i Painters hvori han argumenterede for, at visse ejendommeligheder i malemåde og åbenbare afvigelser fra naturen m.h.t. tegning og farvegivning, som især ses hos mange berømte engelske malere (bl.a. Turner), kan henføres til fejl/forandringer i deres øjne!

I 1877 vendte han tilbage til Paris, hvor han de næste 40 år havde en meget søgt øjenklinik, som stadigt var hans base, da han under ferie traf Lange-Müller i Egypten. Trods alderen var han fortsat aktiv og åbenbart veludrustet til øjenkonsultationer under opholdet. I sidste brev (13.2.13) skriver mormor således, at han har brugt flere timer den dag med "brilleprøver" på morfar, så det havde han altså også i hvert fald en del udstyr med til.

Richard Liebreich var således en yderst kompetent autoritet, hvis store viden og erfaring var indiskutabel. Det fremgår af
Clausens biografi (p. 14), at Lange-Müller's far" tog ham med til Berlin og lod den kendte oftalmolog Gräfe undersøge hans øjne" - uden resultat. Det har været i barndommen eller de første teenage-år men tidsangivelsen mangler. Teoretisk kan det have været mens Liebreich endnu var en af Gräfes 5-6 assistenter og forskede som pioner i arbejdet med oftalmoskopet. Morfar var 12, da Liebreich rejste derfra. Skade, at endnu et halvt århundrede skulle gå før de mødtes, så det blev for sent!
Note:

Tak til forskningsbibliotekar, cand. scient. Kasper Højby Nielsen, Danmarks Naturog Lægevidenskabelige Bibliotek, for hjælp med at identificere Rich. Liebreich og lokalisere hans nekrolog. 